\title{
Incentives encouraging prosumers to knowledge sharing - framework based on Polish study
}

Ewa Ziemba, Faculty of Finance and Insurance, University of Economics in Katowice, ewa.ziemba@ue.katowice.pl

Monika Eisenbardt, Faculty of Finance and Insurance, University of Economics in Katowice, monika.eisenbardt@ue.katowice.pl

\begin{abstract}
Prosumers' knowledge is increasingly becoming an integral and important element in business strategy. A major challenge for enterprises involves motivating prosumers to share their knowledge. This problem is addressed by incentives linked to the knowledge sharing activities of prosumers. The purpose of this paper is to investigate which incentives could encourage prosumers to knowledge sharing with enterprises. Based on a survey producing data from 783 Polish prosumers, this study demonstrates which incentives encourage them to share knowledge. The results indicate that prosumers are willing to share knowledge, but only under the condition of obtaining certain benefits, rewards or fulfilling other personal goals in return. The proposed framework of incentives encouraging prosumers to share knowledge includes tangible and intangible incentives. The named intangible incentives are categorized into activity, social, tooland promotion-related incentives. Tangible and activity incentives mainly encourage prosumers to knowledge sharing. Prosumers award slightly fewer points to social incentives. Meanwhile, tool- and promotion-related incentives have the lowest impact on prosumers' knowledge sharing. Moreover, there are significant relationships between prosumers' gender and all types of incentives; between generations and tangible incentives; as well as between educational background and tangible, activity, social, and tool-related incentives.
\end{abstract}

Keywords: prosumer, prosumption, enterprise, knowledge sharing, incentives, willingness

\section{Introduction}

Knowledge is a strategic advantage which helps enterprises sustain as well as maintain their market competitiveness (Grudzewski, Hejduk, Sankowska, \& Wańtuchowicz, 2013; Kisielnicki, 2014; Krupski, 2014; Nogalski \& Niewiadomski, 2013; Sopińska \& Wachowiak, 2015). Liebowitz (2003) claimed that knowledge related efforts could lead to effectiveness of an enterprise, its efficiency, and productivity. In the recent years, consumer knowledge:

becomes an essential intangible asset for every line of business (Taherparvar, Esmaeilpour, \& Dostar, 2014);

leads to a better response to and respect toward consumers (Aghamirian, Dorri, \& Aghamirian, 2013; Leadbeater, 2008; Reitz, 2012; Sinclaire \& Vogus, 2011; Tapscott \& Williams, 2006);

makes a contribution toward new and innovative products (Brabham, 2012; Gustafsson, Kristensson, Löfgren, \& Witell, 2011; Jurgenson \& Ritzer, 2009; Nasri, 2012; Tsai, Tsai, Li, \& Lin, 2012); 
strengthens bonds between enterprises and prosumers (Morrison \& Crane, 2007; Mróz, 2013; Thomson, MacInnis, \& Park, 2005); and

contributes to the improvement of business value (Croteau \& Li, 2003).

Consumers who share their knowledge with enterprises are known as prosumers; and the process in which they share knowledge with enterprises is known as prosumption (Bylok, 2013; Ritzer \& Jurgenson, 2010; Siuda, 2012; Tapscott \& Williams, 2006; Xie, Bagozzi, \& Troye, 2008). In general, prosumption refers to situations in which prosumers share knowledge not only with enterprises, but also with other prosumers to produce things of value for enterprises, as well as for themselves. In the literature, researchers focused on two different attitudes of individuals toward knowledge sharing which affected the efficiency of knowledge sharing, i.e., willingness and eagerness to share knowledge (De Vries, Van den Hooff, \& De Ridder, 2006; Van den Hooff, De Ridder, \& Aukema, 2004; Tong, Tak, \& Wong, 2013). According to these researchers, prosumers are willing to share knowledge, but only under the condition of obtaining certain benefits in return, such as rewards or fulfilling other personal goals. Furthermore, eagerness for knowledge sharing means that prosumers have an internal drive to share knowledge. They share knowledge without reciprocity and do not expect any tangible benefits from their sharing. The prosumers' willingness and eagerness to share knowledge with enterprises were explored by Ziemba and Eisenbardt (2014).

The literature indicates that incentives play an important role in knowledge sharing. Dermol (2011) examined influences of organizational incentives on knowledge management. Ho and Kuo (2013) indicated that attitude toward incentives has showed a significant effect on knowledge sharing behavior in virtual communities of practice. A study in nine organizations, based in four countries, demonstrated that employees prefer 'soft' incentives for knowledge sharing like acknowledgements and personal development to increases in salary (Gammelgaard, 2007). Iyer and Ravindran (2009) explored the effect of 'usefulness' and 'incentives' on the joint decision to share and use the knowledge objects. The study found when the usefulness level is low an incentive mechanism that rewards the contributor for shared knowledge used by the knowledge user, and the knowledge user for the act of reuse, is more effective than a simple incentive scheme that merely rewards knowledge sharing.

The challenge is how to encourage prosumers to participate in knowledge sharing. Lam and Lambermont-Ford (2010) stressed that encouragement to knowledge sharing is a difficult task. As Liebowitz (2003) noted, some enterprises promote knowledge sharing and retain incentives and rewards until such processes become organizational norms. Therefore, enterprises that have successfully encouraged knowledge sharing among prosumers have exhibited improved organizational performance. Overall, researchers agree that despite the voluminous literature on knowledge management, the association between individual motivation and knowledge sharing remains largely unexplored and poorly understood (Gafni, Geri, \& Bengov, 2014; Lam \& Lambermont-Ford, 2010). Furthermore, after extensively searching the literature, the authors of this paper could not find studies concerning motivation and prosumers' encouragement to knowledge sharing. Thus, there is a need for studying incentives and rewards affecting prosumers' knowledge sharing. This research carried out among Polish prosumers should contribute to greater understanding of the use of incentives for prosumers' knowledge sharing and should help fill the gap in the existing body of knowledge. 
In light of the above limitations, the purpose of this study is to investigate which incentives could encourage prosumers to knowledge sharing with enterprises. Thus, the literature was reviewed, a survey questionnaire was developed, and statistical analysis was employed. The paper is organized as follows: the research questions and hypotheses followed by the research methodology; then results, analysis, and discussion are provided; and the paper concludes with a summary, limitations, and avenues for future research.

\section{Research Questions and Hypotheses}

Some authors stress that an incentive system affects significantly knowledge sharing (Cheng, Ho, $\&$ Lau, 2009). An incentive system and a personal expectation are two significant factors associated with a passion for sharing knowledge. Enterprises should implement and use various incentives to induce prosumers to knowledge sharing (Humphreys \& Grayson, 2008; Gafni et al., 2014). A considerable number of scholars employed a dichotomous method that divides incentives into two parts: intrinsic and extrinsic (Ho \& Kuo, 2013; Löcker et al., 2014). Intrinsic incentives refer to doing something because it is inherently interesting or enjoyable, while extrinsic incentives refer to doing something because it leads to a separable outcome, e.g., money, promotion, profits, career progression, etc. (Ryan \& Deci, 2000).

Another group of scholars separated incentives encouraging knowledge sharing into two types: tangible and intangible (Chouikha, 2016; Janzik \& Herstatt, 2008; Vuori \& Okkonen, 2012). Tangible incentives mainly include monetary compensation, bonus points with financial value, and premiums in the form of free products. There are also intangible incentives enhancing the expertise, status, reputation, and recognition of individuals. This kind of incentives also embraces being part of community, pride of excellence, and need to learn more.

Furthermore, Greenberg and Liebman (1990) suggested that incentives fall into three categories: material, social and activity. Material incentives comprise revenue and financial benefit. Social incentives operate on the interpersonal level by allowing people to identify themselves with the company, co-workers, customers or even competitors. Activity incentives provide opportunities to fulfill individual needs of achievement or growth by offering more new and challenging tasks. Ho and Kuo (2013) confirmed that these kinds of incentives have demonstrated significant influences on the community participants' knowledge sharing behavior. After extensive searching of the literature, only a few studies were found regarding types of incentives encouraging prosumers to knowledge sharing with enterprises. The case studies described by Ziemba and Eisenbardt (2015) indicate that enterprises increasingly use various incentives to encourage prosumers to share knowledge, mainly financial rewards, possibility of adjusting products/services to own needs, building reputation in a society, receiving free samples of products, receiving vouchers, and creating active social networks of customers.

To examine the types of incentives, which are suitable for a prosumption context and prosumers' knowledge sharing with enterprises, this paper focuses on addressing the following research question:

RQ1: What types of incentives encouraging prosumers to knowledge sharing are offered by enterprises and expected by prosumers? 
Some scholars analyzed various personal factors that affect knowledge sharing between employees in organizations. A study carried out in the Central European organizations indicated that the demographic characteristics of employees such as gender and level of education (GrubićNešić, Matić, \& Mitrović, 2015), and age (Bencsik, Juhász, \& Machova, 2014) have a significant impact on knowledge sharing. However, another research carried out in Jordanian enterprises (Almahamid, McAdams, \& Kalaldeh, 2010) and public sector (Hijazi \& Salamah, 2014) found that there are no differences in attitudes toward knowledge sharing according to demographic variables (gender, age, and educational qualification).

Ziemba and Eisenbardt (2014) conducted an analysis of prosumers' eagerness to knowledge sharing, characterized by such criteria as gender, age, Internet access and place of residence. It was shown that the eagerness to knowledge sharing varies depending on prosumers' gender, age, and their place of residence. Additionally, knowledge nearly exclusively was shared by those prosumers who had constant access to the Internet. The others remained passive in this respect. After extensively searching the literature, no other studies concerning a significant association between the types of incentives and demographic characteristics of prosumers were found. Therefore, the paper focuses on addressing the following research question:

RQ2: What are significant associations between the types of incentives expected by prosumers and prosumers' demographic characteristics?

Taking into account the above considerations, four research hypotheses were formulated (in the null form):

H1: Gender of prosumers and types of incentives expected by them are independent;

H2: Age of prosumers and types of incentives expected by them are independent;

H3: Educational background of prosumers and types of incentives expected by them are independent; and

H4: Place of residence of prosumers and types of incentives expected by them are independent.

\section{Research Methodology}

Research methods included a critical review of the literature, logical deduction, case studies, a survey questionnaire, and statistical analysis. The research process took the following steps:

Step 1. A critical review of existing studies related to 'prosumption', 'prosumer', 'customer', 'consumer', 'knowledge sharing', 'incentives', and 'rewards' enabled examination of incentives encouraging consumers/prosumers to knowledge sharing. The review embraces four bibliographic databases: Ebsco, ProQuest, Emerald Management, and ISI Web of Knowledge. In addition, some journals and Web materials dedicated to research on 'consumption' and 'prosumption' were also explored.

Step 2. Case studies of prosumers' knowledge sharing indicate that prosumers are expecting some incentives from enterprises to share knowledge (Ziemba \& Eisenbardt, 2015). Based on the analysis of incentives that enterprises can use to encourage prosumers to share knowledge, a conceptual framework of incentives for prosumers to share knowledge was proposed. 
Step 3. A survey was developed. The questionnaire included questions about enterprise specified incentives employed to encourage prosumers to knowledge sharing. The questions were: (1) Do you need an incentive to share knowledge with enterprises? (2a) Which incentives offered by enterprises encourage you to share knowledge with them? (2b) Which incentives do you expect to encourage you to share knowledge with enterprises? The incentives were listed for questions $2 \mathrm{a}$ and $2 \mathrm{~b}$. For each listed incentive the respondents could choose one of five responses, according to a 5-point Likert scale: (1) definitely no, (2) rather no, (3) neither yes nor no, (4) rather yes, (5) definitely yes.

Step 4. In November 2014, a pilot survey was conducted. The purpose was substantive and methodological scrutiny of the questionnaire. Cronbach's coefficient alpha was used to perform reliability analysis. For all analyzed items the Cronbach's alpha was 0.881. Hinton (2004) suggested four ranges of reliability, i.e., the excellent range ( 0.90 and above), the high $(0.70$ 0.90), the high moderate (0.50-0.70) and the low (0.50 and below). Thus, it can be concluded that the scale had high reliability, and it could be used in the research process. Moreover, substantive scrutiny of the questionnaire enabled to perform minor changes to improve the quality of the questionnaire.

Step 5. Applying the Computer-Assisted Web Interview (CAWI) method and employing the Polish platform Ankietka.pl, the survey questionnaire was uploaded to the website. Data collection took place between December 2014 and March 2015. The survey was presented to a total of 2.500 respondents. After screening responses and excluding outliers, there was a final research sample of 783 usable, correct and complete questionnaires. Therefore, the final response rate was $24.44 \%$. The data was stored in Microsoft Excel format. The demographic analysis of the research sample is presented in Table 1.

Table 1: Demographic analysis of the research sample

\begin{tabular}{|l|r|r|}
\hline \multicolumn{1}{|c|}{ Demographic profile } & $\begin{array}{c}\text { Number of } \\
\text { respondents }\end{array}$ & Percentage \\
\hline Gender & 599 & $76.5 \%$ \\
\hline female & 184 & $23.5 \%$ \\
\hline male & 14 & $1.8 \%$ \\
\hline Age & 35 & $4.5 \%$ \\
\hline Builders generation: over 65 years old & 108 & $13.8 \%$ \\
\hline Baby-Boomers generation: 51-65 years old & 369 & $47.1 \%$ \\
\hline X generation: 36-50 years old & 257 & $32.8 \%$ \\
\hline Y generation: 21-35 years old & 217 & $27.7 \%$ \\
\hline Z generation: less than 21 years old & 559 & $71.4 \%$ \\
\hline Level of education & 7 & $0.9 \%$ \\
\hline higher education & \multicolumn{2}{|l|}{} \\
\hline secondary education & 419 & $53.5 \%$ \\
\hline less than secondary education & 244 & $31.2 \%$ \\
\hline Place of residence & 120 & $15.3 \%$ \\
\hline city with a population of more than 100,000 &
\end{tabular}


The respondents were diverse with respect to their characteristics. With regard to gender, 599 (76.5\%) respondents were female, and $184(23.5 \%)$ were male. This study recommends age ranges defined by McCrindle (2014). The majority of respondents, 369 (47.1\%), were in the range of 21-35 years old, and 257 (32.8\%) of respondents were less than 21 years old. Conversely, $108(13.8 \%)$ of respondents were in the range of 36-50 years old, and $35(4.5 \%)$ of them were in the range of 51-65 years old (Baby-Boomers generation). Finally, only 14 (1.8\%) of the respondents were in the range of over 65 years old (Builders generation). After further analysis, it was decided to merge these two generations. With regard to the level of education, $559(71.4 \%)$ of the respondents completed secondary education while only $217(27.7 \%)$ of them completed higher education. With regard to their place of residence, $419(53.5 \%)$ of respondents lived in cities with a population of more than 100,000 inhabitants, whereas $244(31.2 \%)$ of them lived in cities with a population of fewer than 100,000 inhabitants, and 120 (15.3\%) lived in rural areas.

Step 6. As the process of collecting data was completed the reliability was calculated. The Cronbach's alpha coefficient with all 23 items confirmed a high internal consistency (0.791). Additionally, the values of Cronbach's alpha for each type of incentives and each item, with the assumption that a given item was deleted, were calculated. The Cronbach's 's alpha values for all the items are between 0.572-0.819. The values of Cronbach's alpha coefficient for the respective types of incentives are between 0.748 and 0.804 . The Cronbach's alpha coefficients for all the types of incentives are presented in Table 2.

Table 2: Cronbach's alpha coefficient for all types of incentives

\begin{tabular}{|l|c|c|c|}
\hline \multicolumn{1}{|c|}{ Type of incentives } & $\begin{array}{c}\text { Number } \\
\text { of items }\end{array}$ & $\begin{array}{c}\text { Cronbach's } \\
\text { alpha } \\
\text { coefficient }\end{array}$ & $\begin{array}{c}\text { Minimum value of } \\
\text { Cronbach's alpha } \\
\text { coefficient after deleting } \\
\text { given items }\end{array}$ \\
\hline Tangible incentives & 6 & 0.804 & 0.654 \\
\hline Intangible incentives - activity incentives & 5 & 0.763 & 0.659 \\
\hline Intangible incentives - social incentives & 3 & 0.756 & 0.644 \\
\hline Intangible incentives - tool-related incentives & 6 & 0.769 & 0.743 \\
\hline Intangible incentives - promotion-related incentives & 3 & 0.748 & 0.572 \\
\hline Total & $\mathbf{2 3}$ & $\mathbf{0 . 7 9 1}$ & \\
\hline
\end{tabular}

The analysis showed that the questionnaire scale had high reliability, and it could be used in the research process. The results showed that the removal of some items would not lead to the improvement of internal consistency among items on the scale. Overall, the original alpha scores with all 23 items and the five types of incentives show a strong internal consistency and reliability.

Step 7. To answer the research questions and confirm the research hypotheses, a statistical analysis was employed. The descriptive analysis of incentives was made using the statistics such as the mean, median, and mode. Pearson's Chi-square test $\left(\chi^{2}\right)$ was used for examining independence between demographic characteristics of prosumers and types of incentives. The statistical analysis was made using SPSS software. 


\section{Research Findings}

\section{Framework of incentives to encourage prosumers to knowledge sharing}

As mentioned earlier, scholars examined various incentives encouraging people to knowledge sharing and identified their different types. This study decided to adapt incentives described in the literature and identified in the examined case studies for measuring prosumers' attitudes toward incentives. The conceptual framework, presented in Table 3, specifies the proposed types of incentives and their items.

Table 3: Incentives encouraging prosumers to knowledge sharing

\begin{tabular}{|c|c|}
\hline Type of incentives & Items \\
\hline Tangible incentives & $\begin{array}{l}\text { Financial rewards } \\
\text { Coupons, sweepstakes } \\
\text { Free usage (testing) of prototypes } \\
\text { Free samples of products } \\
\text { Low transaction costs for participation } \\
\text { Bonus points with financial value }\end{array}$ \\
\hline $\begin{array}{l}\text { Intangible } \\
\text { incentives - activity } \\
\text { incentives }\end{array}$ & $\begin{array}{l}\text { Participating in interesting initiatives } \\
\text { Adjustment of products/services to own needs } \\
\text { Enhancement of satisfaction with enterprises and their } \\
\text { products/services } \\
\text { Cooperation with well-known enterprises } \\
\text { Improvement of the products/services quality }\end{array}$ \\
\hline $\begin{array}{l}\text { Intangible } \\
\text { incentives - social } \\
\text { incentives }\end{array}$ & $\begin{array}{l}\text { Cooperation with people who share passions, skill, knowledge, and } \\
\text { experience } \\
\text { Building peer recognition, status, and reputation } \\
\text { Strengthening social ties with enterprises and their customers }\end{array}$ \\
\hline $\begin{array}{l}\text { Intangible } \\
\text { incentives - tool- } \\
\text { related incentives }\end{array}$ & $\begin{array}{l}\text { Utilization of innovative and interesting information and } \\
\text { communications technology (ICT) } \\
\text { Invitation by e-mail } \\
\text { Invitation by Facebook } \\
\text { Interesting blog } \\
\text { Interesting video on YouTube } \\
\text { Online game }\end{array}$ \\
\hline $\begin{array}{l}\text { Intangible } \\
\text { incentives } \\
\text { promotion-related } \\
\text { incentives }\end{array}$ & $\begin{array}{l}\text { Co-creating promotional materials } \\
\text { Promotional or advertising campaign on various media } \\
\text { Promotional information found accidentally }\end{array}$ \\
\hline
\end{tabular}

Within the proposed framework a distinction is made between tangible and intangible incentives. Examples of tangible incentives are incentives as direct financial incentives (e.g., monetary compensation) and indirect financial incentives (e.g., premiums in the form of free products and bonus points with financial value). The named intangible incentives are categorized as followed: 
activity incentives provide opportunities to collaborate with enterprises and co-create things of value by providing more new, innovative and challenging tasks;

social incentives operate on the interpersonal level by allowing prosumers to identify themselves with the enterprise communities, build their reputation and status, enhance skills, as well as collect knowledge and experience;

tool-related incentives refer to information and communications technologies (ICTs), especially tools for online communities, which encourage prosumers to integrate with enterprises' communities; and

promotion-related incentives are related to promotional activities of enterprises encouraging prosumers to share knowledge and co-creating promotional materials.

\section{Incentives expected by prosumers and offered by enterprises}

To answer the first research question concerning types of incentives encouraging prosumers to knowledge sharing, two kinds of analyses were performed. Firstly, prosumers' needs of incentives to share knowledge with enterprises were analyzed. The results are presented in Table 4. Secondly, the types of incentives expected by prosumers to share knowledge in comparison with the kinds of incentives offered to them by enterprises were analyzed. The results are presented in Table 5.

Table 4: The percentage of the prosumers who need incentives to share knowledge

\begin{tabular}{|l|c|}
\hline \multicolumn{1}{|c|}{ Characteristics of prosumers } & $\begin{array}{c}\text { Respondents expecting } \\
\text { incentives }\end{array}$ \\
\hline Gender & $39.9 \%$ \\
\hline female & $45.1 \%$ \\
\hline male & $26.4 \%$ \\
\hline Age & $31.5 \%$ \\
\hline Baby-Boomers and Builders generation & $40.1 \%$ \\
\hline X generation & $49.0 \%$ \\
\hline Y generation & $35.9 \%$ \\
\hline Z generation & $43.1 \%$ \\
\hline Level of education & $42.9 \%$ \\
\hline higher education & $39.1 \%$ \\
\hline secondary education & $44.7 \%$ \\
\hline less than secondary education & $40.8 \%$ \\
\hline Place of residence & \\
\hline city with a population of more than 100,000 & \\
\hline city with a population of less than 100,000 & \\
\hline rural area & \\
\hline
\end{tabular}

The outcomes of the survey indicate that the posture of the significant percentage of prosumers toward knowledge sharing is in tune with 'willingness to share' attitude. They are willing to share knowledge, but in return, they expect specified incentives. Females are a little bit more willing to share knowledge than males, i.e., about $40 \%$ of females and $45 \%$ of males rather or definitely need incentives to share knowledge. With regard to age, elder generations (BabyBoomers, Builders and $\mathrm{X}$ generation) are more willing to share knowledge than younger 
generations ( $\mathrm{Y}$ and $\mathrm{Z}$ generation), i.e., $49 \%$ of $\mathrm{Z}$ generation and only $26.4 \%$ of Baby-Boomers and Builders generation rather or definitely need incentives to share knowledge. Thus, the difference between the oldest and youngest generations is significant (22.6\%). Interestingly, the eldest generations are the closest to an 'eagerness to share' attitude. The majority of them want to share knowledge without expecting incentives and rewards in return. With regard to the level of education, better-educated people are a little bit more willing to share knowledge than less educated ones. The difference between them amounts to 7\%. With regard to the prosumers' place of residence, the outcomes are similar, but prosumers who live in cities with a population of less than 100,000 inhabitants are slightly more willing to share knowledge than others.

Overall, research findings show that a considerable proportion of prosumers needs incentives to share knowledge. Table 5 presents a comparison between incentives offered to prosumers by enterprises and incentives expected by them.

Table 5: Incentives expected by prosumers and offered by enterprises

\begin{tabular}{|l|r|r|r|r|c|c|}
\hline \multirow{2}{*}{\multicolumn{1}{c}{ Types of incentives }} & \multicolumn{2}{c|}{ Expected incentives } & \multicolumn{3}{c|}{ Offered incentives } \\
\cline { 2 - 7 } & Mean & Median & Mode & Mean & Median & Mode \\
\hline Tangible incentives & 3.82 & 4 & 4 & 2.86 & 3 & 3 \\
\hline Intangible incentives - activity incentives & 3.46 & 4 & 4 & 3.16 & 3 & 3 \\
\hline Intangible incentives - social incentives & 3.33 & 3 & 4 & 2.73 & 3 & 3 \\
\hline Intangible incentives - tool-related incentives & 2.72 & 3 & 3 & 2.44 & 2 & 2 \\
\hline Intangible incentives - promotion-related incentives & 2.63 & 3 & 3 & 2.23 & 2 & 2 \\
\hline
\end{tabular}

'Offered incentives' reflect which incentives are currently offered by enterprises to prosumers. It is noticeable that enterprises are mainly encouraging prosumers to knowledge sharing using activity incentives. The mean value is 3.16 . The median and mode values are 3 , indicating that the majority of prosumers do not have an opinion about incentives offered by enterprises. Similar outcomes are in the case of tangible and social incentives. The means values are about 3 in both cases; medians and modes values are 3 . It indicates that prosumers do not have an opinion about such incentives offered to them by enterprises. As to tool-related and promotion-related incentives, the means values are less than 2.5. The medians and modes values are 2 in both cases. Thus, these incentives did not encourage prosumers to share knowledge.

'Expected incentives' reflect which incentives are needed by prosumers to share knowledge and should be offered to them by enterprises. The research findings show that prosumers need tangible and activity incentives. The mean value is 3.82 for tangible incentives, and 3.46 for activity incentives. The median and mode values are 4 in both cases. It can be explained that the majority of prosumers indicated the answer 'rather yes', so they need these incentives to share knowledge with enterprises.

The overall analysis of incentives, presented in Table 5, shows that all mean values of 'Offered incentives' are lower than all mean values of 'Expected incentives'. This indicates that the incentives that are currently offered to prosumers by enterprises do not meet prosumers' 
expectations. Prosumers would like enterprises to offer them more incentives of any type. This could influence their willingness to share knowledge in a positive way.

To answer the second research question, detailed analyses concerning incentives needed by prosumers with regard to their demographic characteristics are presented. Furthermore, the analyses contain only these prosumers who ticked rather yes (4) or definitely yes (5) when answering the question about a prosumers' need of incentives (Table 4) indicating that they rather or definitely need incentives to share knowledge.

\section{Incentives expected by prosumers with regard to their gender}

H1: Gender of prosumers and types of incentives expected by them are independent

The first hypothesis tested whether there is a significant relationship between gender of prosumers and the types of incentives encouraging prosumers to knowledge sharing. The distribution of incentives expected by females and males is shown in Figure 1.

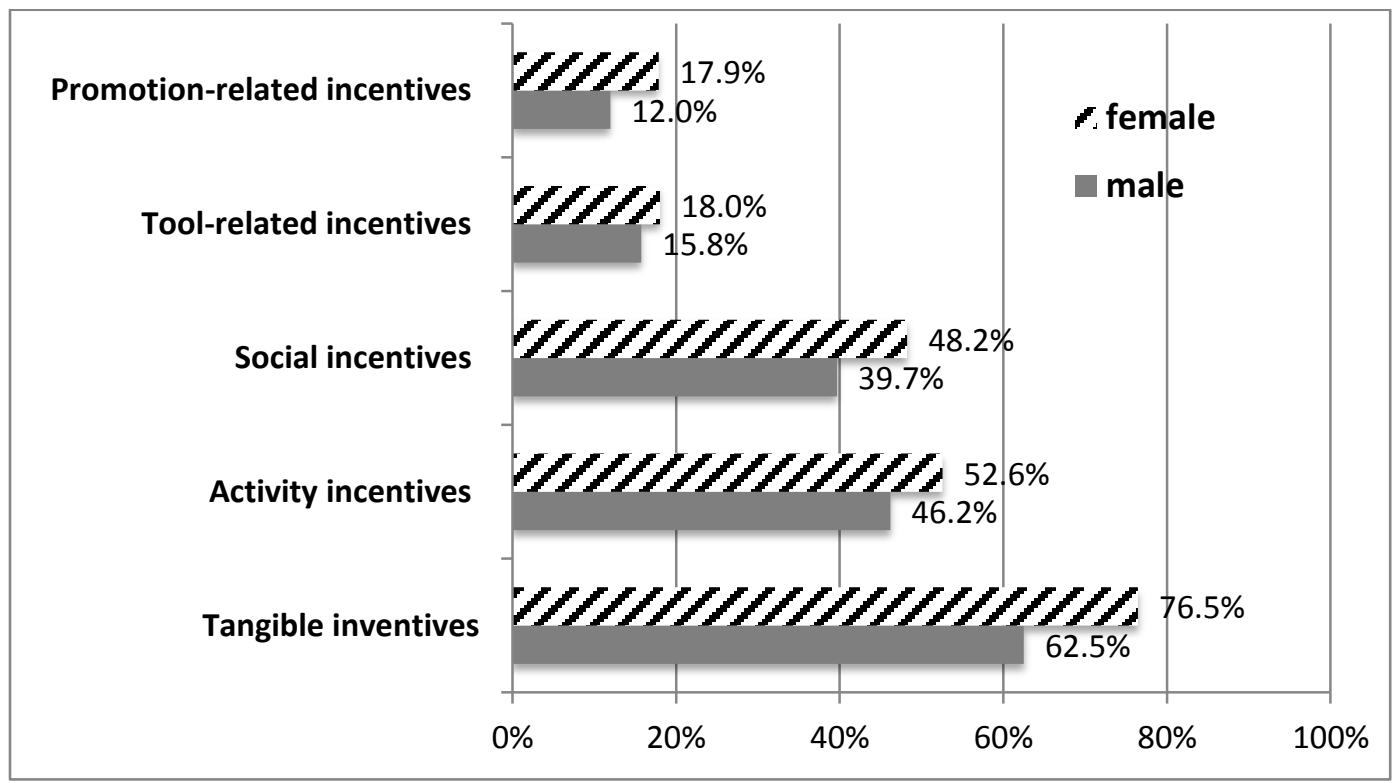

Figure 1: Incentives encouraging females and males to share knowledge.

Figure 1 shows that the large majority of prosumers need tangible incentives, and fewer prosumers prefer activity and social incentives. Tangible incentives are expected by $76.5 \%$ of females and $62.5 \%$ of males. Activity incentives are expected by $52.6 \%$ of females and $46.2 \%$ of males; $48.2 \%$ of females and $39.7 \%$ of males expect social incentives. Therefore, enterprises should offer these kinds of incentives to prosumers to encourage them to share knowledge. Promotion- and tool-related incentives are different. Promotion-related incentives are expected by $17.9 \%$ of females and $12 \%$ of males. Similarly, $18 \%$ of females and only $15.8 \%$ of males expected tool-related incentives. It is possible to draw a conclusion that these incentives do not encourage prosumers to share knowledge. Additionally, females pay more attention to all kinds of incentives, in general. The biggest difference between females and males pertains to tangible incentives. It is $14 \%$ and indicates that tangible incentives are needed more by females for them 
to share knowledge. The Chi-square Pearson's test for independence was employed to determine whether there is a significant relationship between gender of prosumers and types of incentives. The results are presented in Table 6 .

Table 6: Significant association between gender of prosumers and types of incentives

\begin{tabular}{|l|c|c|c|l|l|}
\hline $\begin{array}{c}\text { Gender of prosumers } \\
\text { x Types of incentives }\end{array}$ & \multicolumn{1}{|c|}{$\chi^{\mathbf{2}}$} & \multicolumn{1}{|c|}{$\mathbf{d f}$} & p-value & $\begin{array}{c}\text { Confirmation } \\
\text { of hypothesis }\end{array}$ & \multicolumn{1}{|c|}{ Results } \\
\hline Gender x Tangible & 18.061 & 4 & 0.001 & Not confirmed & $\begin{array}{l}\text { Gender and tangible incentives are not } \\
\text { independent }\end{array}$ \\
\hline Gender x Activity & 21.711 & 4 & 0.000 & Not confirmed & $\begin{array}{l}\text { Gender and activity incentives are not } \\
\text { independent }\end{array}$ \\
\hline Gender x Social & 13.642 & 4 & 0.009 & Not confirmed & $\begin{array}{l}\text { Gender and social incentives are not } \\
\text { independent }\end{array}$ \\
\hline Gender x Tool-related & 18.031 & 4 & 0.001 & Not confirmed & $\begin{array}{l}\text { Gender and tool-related incentives are } \\
\text { not independent }\end{array}$ \\
\hline $\begin{array}{l}\text { Gender x Promotion- } \\
\text { related }\end{array}$ & 27.418 & 4 & 0.000 & Not confirmed & $\begin{array}{l}\text { Gender and promotion-related } \\
\text { incentives are not independent }\end{array}$ \\
\hline
\end{tabular}

\section{Incentives expected by prosumers with regard to their age}

H2: Age of prosumers and types of incentives expected by them are independent

The second hypothesis tested whether there is a significant relationship between age of prosumers and the types of incentives to prosumers' knowledge sharing. The distribution of incentives expected by prosumers with regard to their age is shown in Figure 2.

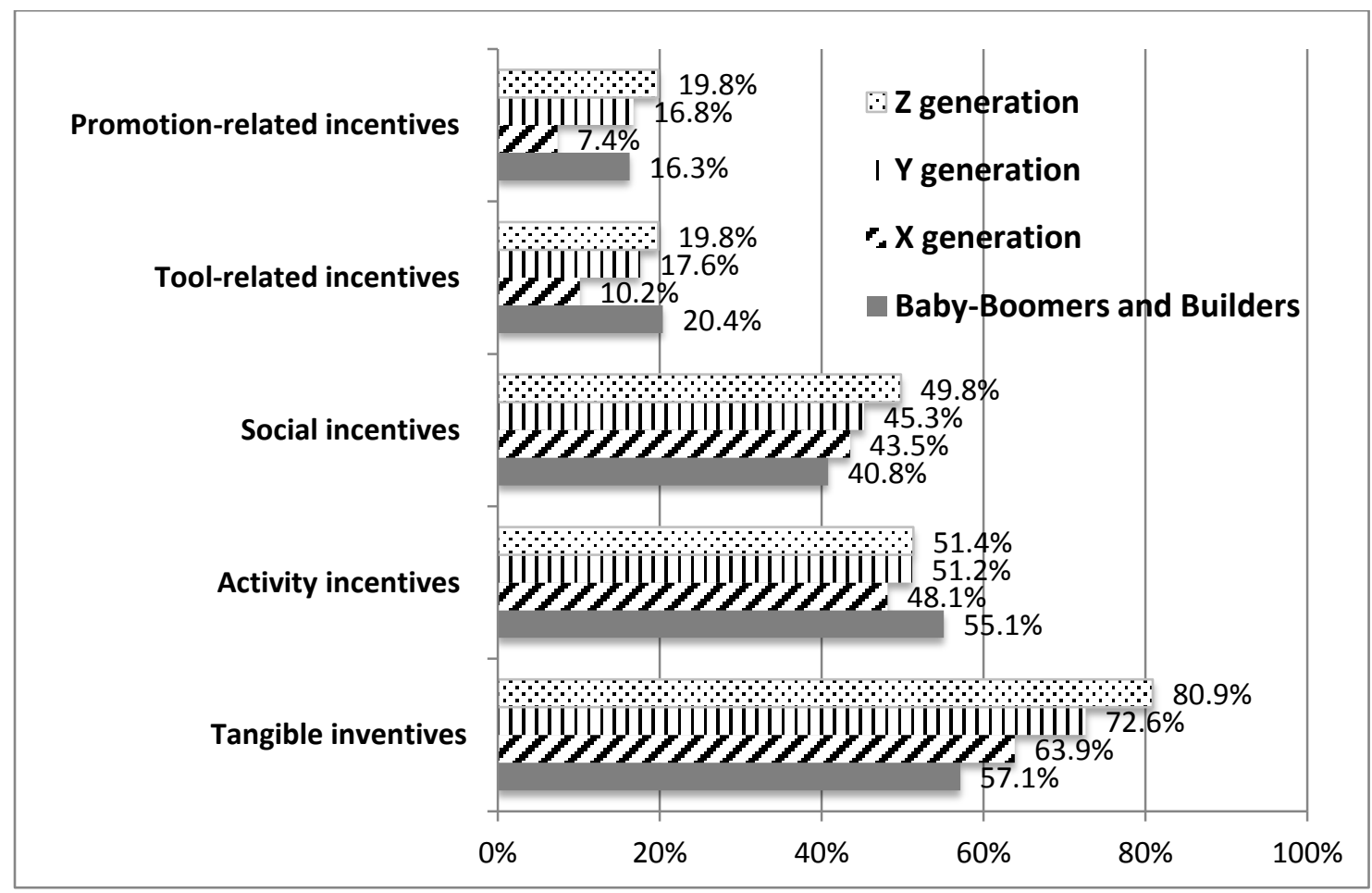

Figure 2: Incentives encouraging prosumers with different age to share knowledge. 
The biggest difference between generations is related to tangible incentives. With regard to prosumers of the Baby-Boomers and the Builders generations, 57.1\% of them expect tangible incentives compared to $80.9 \%$ of prosumers of the $\mathrm{Z}$ generation. The difference between the mentioned generations amounts to $23.8 \%$. Thus, a greater extent of the youngest generation of prosumers expects tangible incentives in comparison with elder generations.

In addition, Figure 2 shows that with regard to activity, social, tools-related, and promotionrelated incentives the preferences of prosumers, classified by their generations, do not vary a lot. About $50 \%$ of prosumers of any generation prefer activity incentives. Thus, these incentives can encourage knowledge sharing of about $50 \%$ of prosumers, regardless of the generation. Social incentives are more needed by younger generations than elder ones, but the difference is not as significant as in the case of tangible incentives. The difference between the youngest and eldest generations amounts to $9 \%$. As to tool- and promotion-related incentives, the percentage of prosumers who need them is significantly lower. In comparison with other generations, the $\mathrm{X}$ generation expects these incentives to a lower extent. Merely $7.4 \%$ of prosumers of the $\mathrm{X}$ generation indicated that they need promotion-related incentives, and thus this type of incentive can encourage them to knowledge sharing. Similarly, only $10.2 \%$ of them need tool-related ones.

The Chi-square Pearson's test for independence was employed to determine whether there is a significant relationship between age of prosumers and types of incentives. The results are presented in Table 7.

Table 7: Significant association between age of prosumers and types of incentives

\begin{tabular}{|l|r|r|r|l|l|}
\hline $\begin{array}{c}\text { Age of prosumers x } \\
\text { Types of incentives }\end{array}$ & \multicolumn{1}{c|}{$\chi^{\mathbf{2}}$} & \multicolumn{1}{c|}{ df } & p-value & $\begin{array}{l}\text { Confirmation } \\
\text { of hypothesis }\end{array}$ & \multicolumn{1}{|c|}{ Results } \\
\hline Age x Tangible & 31.960 & 12 & 0.001 & Not confirmed & $\begin{array}{l}\text { Age and tangible incentives are not } \\
\text { independent }\end{array}$ \\
\hline Age x Activity & 6.930 & 12 & 0.862 & Confirmed & $\begin{array}{l}\text { Age and activity incentives are } \\
\text { independent }\end{array}$ \\
\hline Age x Social & 5.938 & 12 & 0.919 & Confirmed & $\begin{array}{l}\text { Age and social incentives are } \\
\text { independent }\end{array}$ \\
\hline Age x Tool-related & 16.308 & 12 & 0.178 & Confirmed & $\begin{array}{l}\text { Age and tool-related incentives are } \\
\text { independent }\end{array}$ \\
\hline $\begin{array}{l}\text { Age x Promotion- } \\
\text { related }\end{array}$ & 12.996 & 12 & 0.369 & Confirmed & $\begin{array}{l}\text { Age and promotion-related incentives } \\
\text { are independent }\end{array}$ \\
\hline
\end{tabular}

To sum up, the analysis of incentives expected by different generations of prosumers shows that the majority of them prefer tangible incentives, and then activity and social incentives. It is possible to draw a conclusion that enterprises should employ these incentives to encourage prosumers of any generation to share knowledge.

\section{Incentives expected by prosumers with regard to their educational background}

H3: Educational background of prosumers and types of incentives expected by them are independent 
The third hypothesis tested whether there is a significant relationship between educational background of prosumers and the types of incentives to prosumers' knowledge sharing. The distribution of incentives expected by prosumers with regard to their educational background is shown in Figure 3.

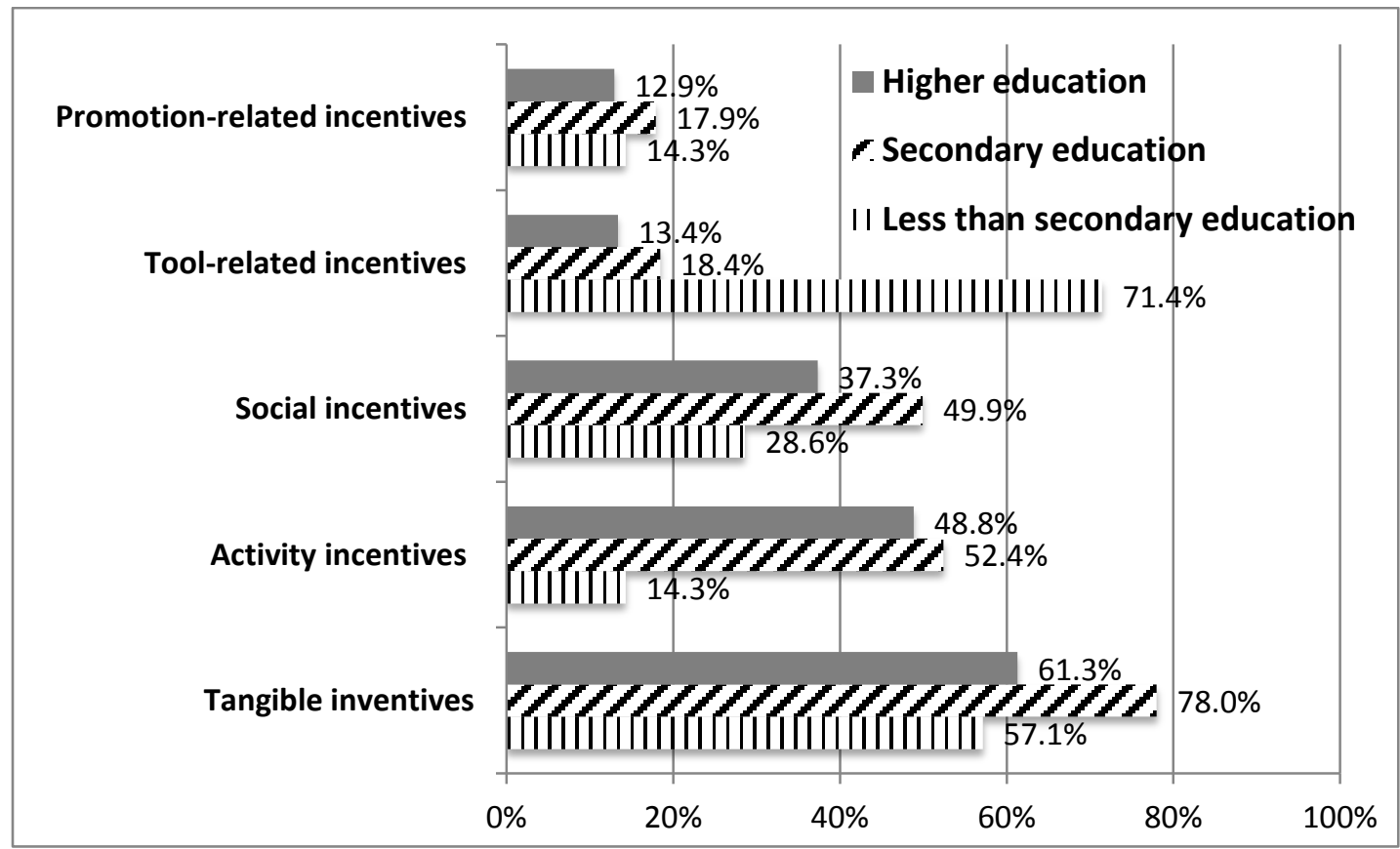

Figure 3: Incentives encouraging prosumers with different educational background to share knowledge.

There are significant differences between incentives expected by prosumers depending on their educational background. Prosumers with secondary education to a greater extent need tangible incentives - indicated by $78 \%$ of them in comparison to $61.3 \%$ of prosumers with higher education and $57.1 \%$ of prosumers with lesser than secondary education. Furthermore, a large majority of prosumers with secondary education need activity incentives - indicated by $52.4 \%$ of them in comparison with $48.8 \%$ of prosumers with higher education, and merely $14.3 \%$ of prosumers with lesser than secondary education. Social incentives are also more expected by prosumers with secondary education - indicated by $49.9 \%$ of them in comparison with $37.3 \%$ of prosumers with higher education and $28.6 \%$ of prosumers with less than secondary education.

The interesting outcome of the survey is that prosumers with less than secondary education more need tool-related incentives than other prosumers. This kind of incentives was indicated by $71.4 \%$ of them. Other prosumers do not need tool- or promotion-related incentives to share knowledge. Thus, between $12.9 \%$ and $18.4 \%$ of prosumers with higher or secondary educational background indicated these kinds of incentives as expected by them.

The Chi-square Pearson's test for independence was employed to determine whether there is a significant relationship between educational background of prosumers and types of incentives. The results are presented in Table 8. 
Table 8: Significant association between educational background of prosumers and types of incentives

\begin{tabular}{|l|c|c|c|l|l|}
\hline $\begin{array}{c}\text { Educational } \\
\text { background of } \\
\text { prosumers x Types of } \\
\text { incentives }\end{array}$ & $\chi^{\mathbf{2}}$ & df & p-value & $\begin{array}{c}\text { Results } \\
\text { Confirmation } \\
\text { of hypothesis }\end{array}$ & \multicolumn{1}{|c|}{} \\
\hline $\begin{array}{l}\text { Educational background } \\
\text { x Tangible }\end{array}$ & 26.233 & 8 & 0.001 & Not confirmed & $\begin{array}{l}\text { Educational background and tangible } \\
\text { incentives are not independent }\end{array}$ \\
\hline $\begin{array}{l}\text { Educational background } \\
\text { x Activity }\end{array}$ & 24.683 & 8 & 0.002 & Not confirmed & $\begin{array}{l}\text { Educational background and activity } \\
\text { incentives are not independent }\end{array}$ \\
\hline $\begin{array}{l}\text { Educational background } \\
\text { x Social }\end{array}$ & 18.831 & 8 & 0.016 & Not confirmed & $\begin{array}{l}\text { Educational background and social } \\
\text { incentives are not independent }\end{array}$ \\
\hline $\begin{array}{l}\text { Educational background } \\
\text { x Tool-related }\end{array}$ & 30.752 & 8 & 0.000 & Not confirmed & $\begin{array}{l}\text { Educational background and tool- } \\
\text { related incentives are not independent }\end{array}$ \\
\hline $\begin{array}{l}\text { Educational background } \\
\text { x Promotion-related }\end{array}$ & 9.282 & 8 & 0.319 & Confirmed & $\begin{array}{l}\text { Educational background and } \\
\text { promotion-related incentives are } \\
\text { independent }\end{array}$ \\
\hline
\end{tabular}

To sum up, there are considerable differences between the preferences of incentives depending on prosumers' educational background. Prosumers with secondary education are most willing for all kinds of incentives, except the tool-related incentives. To a greater extent, these incentives are needed by prosumers with less than secondary education.

\section{Incentives expected by prosumers with regard to their place of residence}

H4: Place of residence of prosumers and types of incentives expected by them are independent

The fourth hypothesis tested whether there is a significant relationship between place of residence of prosumers and the types of incentives to prosumers' knowledge sharing. The distribution of incentives expected by prosumers with regard to their place of residence is shown in Figure 4.

The findings show that there are no significant differences in incentives needed by prosumers depending on their place of residence. In the case of tangible incentives the difference between prosumers is about $4.0 \%$. This indicates that prosumers living in rural areas slightly more expect these incentives in comparison with others prosumers. Activity incentives are slightly more needed by prosumers living in cities with a population of more than 100.000 inhabitants. The differences between them and prosumers living in rural areas and cities with a population of less than 100.000 inhabitants are respectively $4.3 \%$ and $1.9 \%$. Similarly, prosumers living in rural areas and cities with a population of more than 100,000 inhabitants slightly more need social incentives in comparison with prosumers living in cities with a population of less than 100,000 inhabitants. This difference is about 5.0\%. 


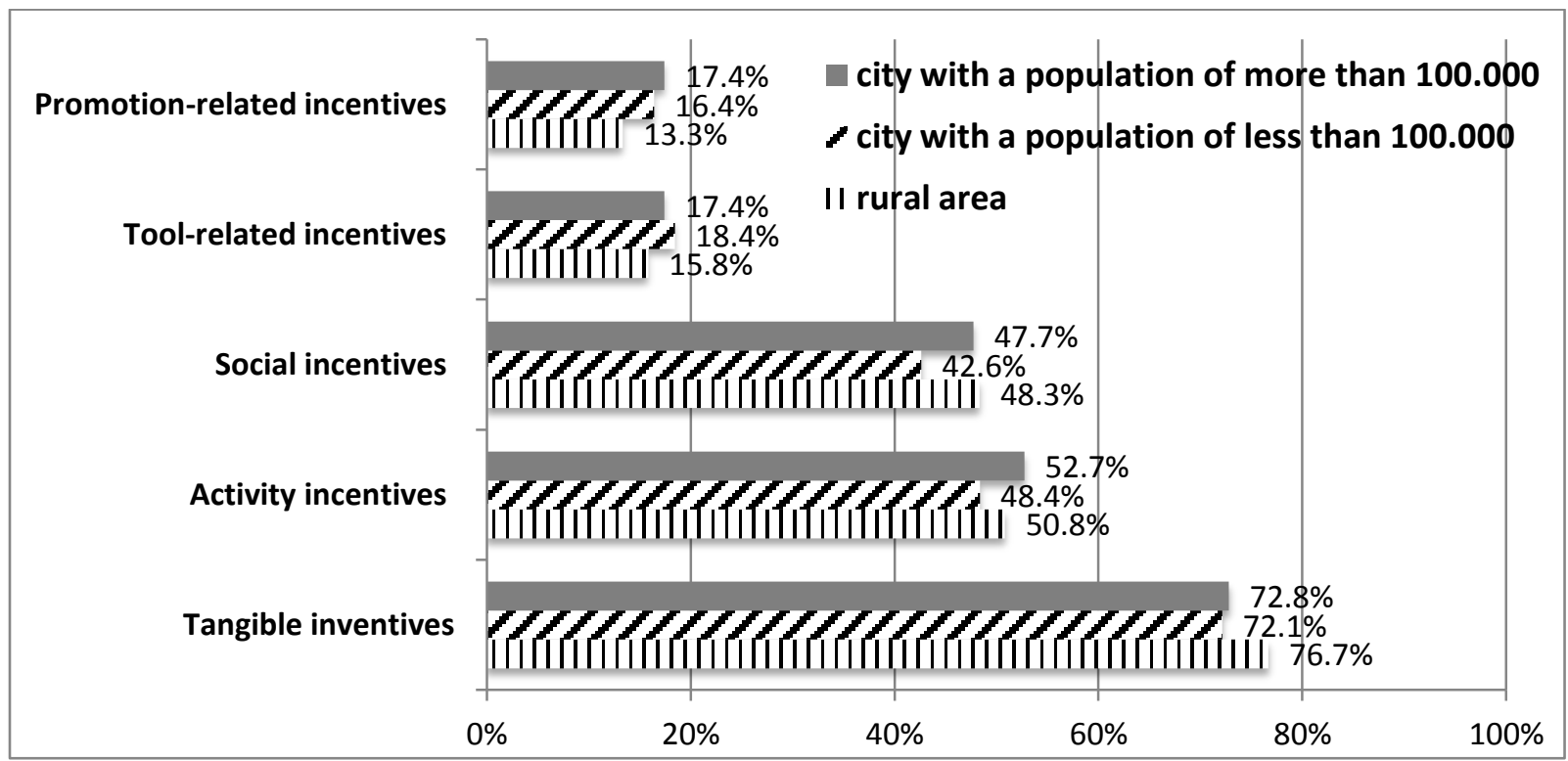

Figure 4: Incentives encouraging prosumers with regard to their place of residence to share knowledge.

The Chi-square Pearson's test for independence was employed to determine whether there is a significant relationship between place of residence of prosumers and types of incentives. The results are presented in Table 9.

Table 9: Significant association between place of residence of prosumers and types of incentives

\begin{tabular}{|l|c|c|c|l|l|}
\hline $\begin{array}{l}\text { Place of residence of } \\
\text { prosumers x Types of } \\
\text { incentives }\end{array}$ & $\boldsymbol{\chi}^{\mathbf{2}}$ & $\mathbf{d f}$ & $\mathbf{p}$-value & $\begin{array}{c}\text { Confirmation } \\
\text { of hypothesis }\end{array}$ & \multicolumn{1}{|c|}{ Results } \\
\hline $\begin{array}{l}\text { Place of residence } \mathrm{x} \\
\text { Tangible }\end{array}$ & 8.874 & 8 & 0.353 & Confirmed & $\begin{array}{l}\text { Place of residence and tangible } \\
\text { incentives are independent }\end{array}$ \\
\hline $\begin{array}{l}\text { Place of residence } \mathrm{x} \\
\text { Activity }\end{array}$ & 11.600 & 8 & 0.170 & Confirmed & $\begin{array}{l}\text { Place of residence and activity } \\
\text { incentives are independent }\end{array}$ \\
\hline $\begin{array}{l}\text { Place of residence } \mathrm{x} \\
\text { Social }\end{array}$ & 5.309 & 8 & 0.724 & Confirmed & $\begin{array}{l}\text { Place of residence and social incentives } \\
\text { are independent }\end{array}$ \\
\hline $\begin{array}{l}\text { Place of residence } \mathrm{x} \\
\text { Tool-related }\end{array}$ & 13.068 & 8 & 0.110 & Confirmed & $\begin{array}{l}\text { Place of residence and tool-related } \\
\text { incentives are independent }\end{array}$ \\
\hline $\begin{array}{l}\text { Place of residence } \mathrm{x} \\
\text { Promotion-related }\end{array}$ & 11.435 & 8 & 0.3178 & Confirmed & $\begin{array}{l}\text { Place of residence and promotion- } \\
\text { related incentives are independent }\end{array}$ \\
\hline
\end{tabular}

\section{Conclusions}

\section{Research contribution}

This work contributes to extant research on prosumption by: indicating types of incentives currently offered by enterprises to encourage prosumers to knowledge sharing; indicating types of incentives expected by prosumers to share knowledge; and identifying significant association between demographic characteristics of prosumers and types of incentives expected by them. 
Firstly, this study indicates that prosumers want to share their knowledge but in exchange for specified incentives, especially tangible ones, i.e., financial and material rewards, testing of prototypes, free samples of products, low transaction costs for participation, and bonus points with financial value. Intangible incentives named activity incentives are viewed by prosumers as less important than tangible ones. They embrace participating in interesting initiatives, adjustment of products/services to meet needs, enhancement of satisfaction with enterprises and their products/services, cooperation with well-known enterprises, and improvement of the products/services quality. Prosumers award slightly fewer points to social incentives, such as cooperation with people who share passions, skill, knowledge, and experience, building peer recognition, status, reputation, and strengthening social ties with enterprises and their customers. Meanwhile, promotion-related (i.e., co-creating promotional materials, promotional or advertising campaign in various media, promotional information found accidentally) and toolrelated (i.e., utilization of interesting and innovative ICTs, invitation by e-mail, invitation by Facebook, interesting blog, interesting video on YouTube, online games) incentives have the lowest impact on prosumers' knowledge sharing.

Secondly, the outcomes show that prosumers' expectations differ from incentives offered by enterprises nowadays. Enterprises mainly offer intangible incentives named activity incentives to encourage prosumers to share knowledge, but prosumers prefer tangible ones.

Thirdly, this study examines the significant association between demographic characteristics of prosumers (i.e., gender, age, educational background and place of residence) and the type of incentives expected by them. There are significant relationships between gender of prosumers and all types of incentives; between generation and tangible incentives; as well as between educational background and tangible, activity, social and tool-related incentives. There are no relationships between prosumers' place of residence and types of incentives; between generation and activity, social, tool- and promotion-related incentives; as well as between educational background and promotion-related incentives. First of all, women, generation $\mathrm{Z}$ and prosumers with a secondary education expected more tangible incentives than men, other generations, and persons with other educational backgrounds. Activity incentives are more welcome by women and prosumers with a secondary education than for other prosumers. Social incentives are more favored by women than by men, and by prosumers with a secondary education than with other types of education.

\section{Implication for rresearch and practice}

This study can be useful for researchers. They may use this methodology and do similar analyses with different sample groups in Poland and other countries, additionally many comparisons between different groups and countries can be made. Moreover, the methodology constitutes a very comprehensive basis for identifying incentives to encourage prosumers to knowledge sharing, but researchers may develop, verify and improve this methodology and its implementation. In addition, researchers may use these research findings and employ them in studies of enterprises. Their goal could be the analysis of incentives offered to prosumers from the enterprise perspective and the possibilities for adjusting the incentives to the expectations of prosumers. 
Moreover, for practitioners, the results of this study can be used to improve activities aimed at prosumption adoption, especially helping them understand which incentives are expected by prosumers to share knowledge.

\section{Limitation and future research}

As with many other studies, this study has its limitations. The first one was the selection of the survey respondents. Most of them were young people below 35 years old. It is advisable to extend the future research to elderly persons, among others prosumers $50+$. The second limitation is methodological. The research sample embraced only prosumers, not enterprises. It is advisable to extend the research to enterprises. The third limitation was the integration of all forms of prosumers knowledge sharing (e.g., evaluating, commenting, testing, upgrading, and creating products or services) in one category. It is advisable to carry out an in-depth research on specific forms of prosumers' engagement concerning various incentives expected by them. All these issues should be carefully considered and assimilated in the future works.

\section{Acknowledgement}

This research has been supported by a grant entitled "Transformation of business and public administration by information technology and information systems" from the University of Economics in Katowice, Poland, 2014-2016.

\section{References}

Aghamirian, B., Dorri, B., \& Aghamirian, B. (2013). Effects of customer knowledge management's eight factors in e-commerce. Management Science and Engineering, 7(4), $1-11$.

Almahamid, S., McAdams, A.C., \& Kalaldeh, T. (2010). The relationships among organizational knowledge sharing practices, employees' learning commitments, employees' adaptability, and employees' job satisfaction: An empirical investigation of the listed manufacturing companies in Jordan. Interdisciplinary Journal of Information, Knowledge, and Management, 5, 327-325.

Bencsik, A., Juhász, T., \& Machova, R. (2014). Mentoring practice on behalf of knowledge sharing in the light of education. Acta Polytechnica Hungarica, 11(9), 95-114.

Brabham, D.C. (2012). Motivations for participation in a crowdsourcing application to improve public engagement in transit planning. Journal of Applied Communication Research, 40(3), 307-328.

Bylok, F. (2013). Konsumpcja, konsument i społeczeństwo konsumpcyjne we współczesnym świecie [Consumption, the consumer and the consumer society in the modern world]. Katowice: Śląsk.

Cheng, M.Y., Ho, J.S.Y., \& Lau, P.M. (2009). Knowledge sharing in academic institutions: A study of multimedia university Malaysia. Electronic Journal of Knowledge Management, 3(7), 313-324. 
Chouikha, M.B. (2016). Organizational design for knowledge management. London: John Wiley and Sons.

Croteau, A. M. \& Li, P. (2003). Critical success factors of CRM technological initiatives. Canadian Journal of Administrative Sciences, 20(1), 21-34.

Dermol, V. (2011). Incentives for knowledge management and organisational performance. Proceedings of Management, Knowledge and Learning International Conference MakeLear, 22-24 June 2011, Celje, Slovenia, 345-353.

De Vries, R.E., Van den Hooff, B., \& De Ridder, J.A. (2006). Explaining knowledge sharing: The role of team communication styles, job satisfaction and performance beliefs. Communication Research, 33(2), 115-135.

Gafni, R., Geri, N., \& Bengov, P. (2014). Investigating the effect of tangible and virtual rewards on knowledge contribution in online communities. Online Journal of Applied Knowledge Management, 2(2), 1-11.

Gammelgaard, J. (2007). Why not use incentives to encourage knowledge sharing? Journal of Knowledge Management Practice, 8(1), Retrieved January 20, 2015, from http://www.tlainc.com/articl127.htm

Greenberg, J. \& Liebman, M. (1990). Incentives: the missing link in strategic performance. Journal of Business Strategy, 11(4), 8-11.

Grubić-Nešić, L., Matić, D., \& Mitrović, S. (2015). The influence of demographic and organizational factors on knowledge sharing among employees in organizations. Tehnički Vjesnik, 22(4), 1005-1010.

Grudzewski, W.M., Hejduk, I.K., Sankowska, A., \& Wańtuchowicz, M. (2013). Sustainability $w$ biznesie czyli przedsiębiorstwo przyszłości. Zmiany paradygmatów $i$ koncepcji zarzadzania [Sustainability in business i.e., enterprise of the future. Paradigms and management concepts changes]. Warszawa: Poltex.

Gustafsson, A., Kristensson, P., Löfgren, M., \& Witell, L. (2011). Idea generation: customer cocreation versus traditional market research techniques. Journal of Service Management, $22(2), 140-159$.

Hijazi, H.A. \& Salamah, H. (2014). Impact of social capital on knowledge sharing at the public sector in Jordan. Information and Knowledge Management, 4(1), 20-30.

Hinton, P. (2004). Statistics explained: A guide for social science students. New York: Routledge.

Ho, L.A. \& Kuo, T.H. (2013). How system quality and incentive affect knowledge sharing. Industrial Management \& Data Systems, 113(7), 1048-1063.

Humphreys, A. \& Grayson, K. (2008). The intersecting roles of consumer and producer: A critical perspective on co-production, co-creation and prosumption. Sociology Compass, 2(3), 963-980. Retrieved March 20, 2013, from http://www.kentgrayson.com

Iyer, G.S. \& Ravindran, S. (2009). Usefulness, incentives and knowledge management. Journal of Knowledge Management, 13(6), 410-430. 
Janzik, L. (2010). Contribution and participation in innovation communities: A classification of incentives and motives. International Journal of Innovation and Technology Management, 7(3), 247-262.

Janzik, L. \& Herstatt, C. (2008). Innovation communities: Motivation and incentives for community members to contribute. Proceedings of the 4th IEEE International Conference on Management of Innovation and Technology, 21-24 September 2008, Bangkok, Thailand, 350-355.

Jurgenson, N. \& Ritzer, G. (2009). Efficiency, effectiveness, and Web 2.0. In S. Kleinman (Ed.), The culture of efficiency, New York: Peter Lang Publishing, 51-67.

Kisielnicki, J. (2014). Zarządzanie. Jak zarzadzać i być zarzadzanym [Management. How to manage and be managed]. Warszawa: PWE.

Krupski, R. (2014). Zasoby niematerialne jako główny składnik strategii przedsiębiorstwa działającego $\mathrm{w}$ turbulentnym, nieprzewidywalnym otoczeniu [Intangible resources as a main component of the business strategy in turbulent, unpredictable environment]. Organizacja i Kierowanie [Organization and Management], 1A(159), 87-98.

Lam, A. \& Lambermont-Ford, J.P. (2010). Knowledge sharing in organisational contexts: A motivation-based perspective. Journal of Knowledge Management, 14(1), 51-66.

Leadbeater, C. (2008). We-think. Mass innovation, not mass production. London: Profile Books.

Liebowitz, J. (2003). A knowledge management strategy for Jason organization: A case study. Journal of Computer Information Systems, 44(2), 1-5.

Löcker, A.K., Eraßme, D., Jakobs, E.M., Schaar, A.K., Valdez, A.C., \& Ziefle. M. (2014). Yet another platform? Motivational factors for using online communities in business contexts. Proceedings of the 5th International Conference on Applied Human Factors and Ergonomics AHFE 2014, 19-23 July 2014, Krakow, Poland, 1145-1156.

McCrindle, M. (2014). The ABC of XYZ. Understanding of global generations. Bella Vista: McCrindle Research.

Morrison, S. \& Crane, F.G. (2007). Building the service brand by creating and managing an emotional brand experience. Journal of Brand Management, 14, 410-421.

Mróz, B. (2013). Konsument w globalnej gospodarce. Trzy perspektywy [Consumer in the global economy. Three approaches]. Warszawa: Szkoła Główna Handlowa Press.

Nasri, G. (2012). Why consumers are increasingly eager to trade data for personalization. Retrieved March 01, 2014, from http://www.digitaltrends.com/social-media/whyconsumers-are-increasingly-eager-to-trade-data-for-personalization

Nogalski, B. \& Niewiadomski, P. (2013). Absorbcja wiedzy inżynierskiej w praktyce zarządzania - kontekst strategii przywództwa kosztowego [Absorption of the engineering knowledge in management practice]. Organizacja $i$ Kierowanie [Organization and Management], 5(158), 11-29.

Reitz, A. (2012). Social media's function in organizations: A functional analysis approach. Global Media Journal, 5(2), 41-56. 
Ritzer, G. \& Jurgenson, N. (2010). Production, consumption, prosumption: The nature of capitalism in the age of the digital 'prosumer'. Journal of Consumer Culture, 10(1), 13-36.

Ryan, R.M. \& Deci, E.L. (2000). Intrinsic and extrinsic motivations: Classic definitions and new directions. Contemporary Educational Psychology, 25, 54-67.

Sinclaire, J.K. \& Vogus, C.E. (2011). Adoption of social networking sites: An exploratory adaptive structuration perspective for global organizations. Information Technology and Management, 12(4), 294-314.

Siuda, P. (2012). Mechanizmy kultury prosumpcji, czyli fani i ich globalne zróżnicowanie [Mechanisms of prosumption culture, i.e., the fans and their global diversity]. Studia Socjologiczne, 4(207), 109-132.

Sopińska, A. \& Wachowiak P. (2015). Kultura organizacyjna a gotowość pracowników do dzialenia się wiedzą [Organizational culture and the willingness of employees to share knowledge]. In K. Perechuda \& I. Chomiak-Orsa (Eds.), Wiedza i informacja $w$ akceleracji biznesu [Knowledge and information to accelerate business], 31-40, Częstochowa: Wydział Zarządzania Politechniki Częstochowskiej Press.

Taherparvar, N., Esmaeilpour, R., \& Dostar, M. (2014). Customer knowledge management, innovation capability, and business performance: A case study of the banking industry. Journal of Knowledge Management, 3(18), Retrieved May 12, 2014, from http://www.emeraldinsight.com/journals.htm?issn=1367-3270\&volume=18\&issue=3

Tapscott, D. \& Williams, A.D. (2006). Wikinomics: How mass collaboration changes everything. New York: Penguin Group.

Thomson, M., MacInnis, D.J., \& Park, C.W. (2005). The ties that bind: Measuring the strength of consumers' emotional attachments to brands. Journal of Consumer Psychology, 1(15), 77-91.

Tong, C., Tak, W.I.W., \& Wong, A. (2013). The impact of knowledge sharing on the relationship between organizational culture and job satisfaction: The perception of information communication and technology (ICT) practitioners in Hong Kong. International Journal of Human Resource Studies, 1(3), 9-37.

Tsai, W., Tsai, M., Li, S., \& Lin, C. (2012). Harmonizing firms' knowledge and strategies with organizational capabilities. Journal of Computer Information Systems, 53(1), 23-32.

Van den Hooff, B., De Ridder, J., \& Aukema, E. (2004). Exploring the eagerness to share knowledge: The role of social capital and ICT in knowledge sharing. In M. Huysman \& V. Wulf (Eds.), Social Capital and Information Technology, 7, 163-186. Cambridge: The MIT Press.

Vuori, V. \& Okkonen, J. (2012). Knowledge sharing motivational factors of using an intraorganizational social media platform. Journal of Knowledge Management, 16(4), 592603.

Xie, C., Bagozzi, R.P., \& Troye, S.V. (2008). Trying to prosume: Toward a theory of consumers as co-creators of value. Journal of the Academy of Marketing Science, 36, 109-122. 
Ziemba, E. \& Eisenbardt, M. (2014). Prosumers' eagerness for knowledge sharing with enterprises - a Polish study, Online Journal of Applied Knowledge Management, 2(1), 40-58.

Ziemba, E. \& Eisenbardt, M. (2015). Prosumers' participation in business processes. Online Journal of Applied Knowledge Management, 3(1), 114-127.

\section{Authors Biographies}

Ewa Ziemba completed her Ph.D. and Post Ph.D. in Management, with a major focus on management information systems. She is an Associate Professor at the University of Economics, Katowice, Poland. Her current research focuses on information systems and technologies for business and public administration transformation. She has published over 170 peer-reviewed papers and 16 books, and has played an instrumental role in prestigious Polish and international research projects. Ewa Ziemba serves on the editorial boards of several international journals, and is the Founding Editor-in-Chief of The Online Journal of Applied Knowledge Management. She is also the Vice President for Research Collaborations of the International Institute for Applied Knowledge Management. Ewa Ziemba has received numerous awards for research and teaching, including The Excellent Award of the President of the University of Economics in Katowice, The Silver Cross of Merit from the President of Poland, The Medal of the National Education Commission from the Ministry of National Education in Poland, and The Award of Fellow \& Distinguished Scholar from the International Institute for Applied Knowledge Management, and several The Best Papers awards.

Monika Eisenbardt, completed her Ph.D. with a major focus on management information systems. She is an Assistant at the University of Economics, Katowice. Her current research focuses on knowledge-based organizations, especially information systems and technologies for prosumption. She has received two The Best Paper awards at the international conferences. 